\title{
PHYSICOCHEMICAL PROPERTIES OF FLOUR AND STARCH FROM TWO CASSAVA VARIETIES
}

\author{
1*Oyeyinka, S. A., ${ }^{2}$ Adeloye, A. A.., ${ }^{1}$ Smith, S. A., ${ }^{1}$ Adesina, B. O., and ${ }^{3}$ Akinwande, F. F. \\ 1Department of Home Economics and Food Science, University of llorin, Nigeria \\ 2Department of Animal production, University of Ilorin, Nigeria \\ 3Department of Food Technology, Yaba College of Technology, Nigeria
}

*Corresponding author: sartf2001@yahoo.com;oyeyinka.sa@unilorin.edu.ng; (+2347066395421)

\begin{abstract}
In this study, the physicochemical properties of flour and starch from two cassava varieties (TME 419 and TMS 326) were determined using standard methods. Cassava roots were obtained from University of llorin Agricultural research farm. Proximate composition of TME 419 cassava were different from that of TMS 326 roots. The two cassava roots had carbohydrate as their major components (approx. 84\%). TMS 326 showed significantly higher protein, fats and ash contents than the TME 419 genotype. Amylose content (approx. $27 \%$ ) of TMS 326 starch was higher than TME 419 starch (approx. 22\%). Cassava starch granules of both varieties had smooth surfaces with mostly round granules while some granules were spherical, elongated and irregular in shape. TME 419 had smaller granule (approx. $11 \mu \mathrm{m}$ ) compared to that of TMS $326(13 \mu \mathrm{m})$. Both starch type showed the A-type crystallinity pattern. The peak gelatinisation temperature of TMS 326 starch (approx.71 ${ }^{\circ} \mathrm{C}$ ) was higher than that of TME 419 starch (approx. $61^{\circ} \mathrm{C}$ ). Peak viscosity of TMS 326 starch was significantly $(p<0.05)$ higher than that of TME 419 starch, which could be related to the higher amylose content. However, the peak viscosity of flour from TME 419 cassava was significantly $(p<0.05)$ higher than that of TMS 326. Cassava starches displayed higher swelling power than the flour samples. TME 419 flour and starch showed higher swelling power and cold paste viscosity suggesting that the starch could be used as thickening agents in various food applications.
\end{abstract}

Keywords: Cassava, Flour, Starch, Pasting properties, Functional properties 


\section{INTRODUCTION}

Root and tuber crops such as yam and cassava are second only in importance to cereals as a global source of carbohydrates (Oladipo et al., 2017). However, cassava is the second most important tropical root crop in West Africa (Adisa et al., 2015; Falola et al., 2017). Cassava (Manihot esculenta) is a root crop that is consumed in many parts of the world. It is drought tolerant and can withstand harsh climatic conditions and can thrive well on poor soils and marginal lands (Ezui et al., 2018). Cassava root is a starchy crop that has been processed into various forms for utilisation. For example, it may be processed into high quality cassava flour (HQCF). HQCF is an unfermented cassava product that has been successfully used as a partial and complete replacement for wheat flour in processing of bread, cookies, and other confectioneries (Maziya-Dixon et al., 2017). In Nigeria and some parts of the tropics, cassava roots are processed into traditionally fermented food products such as gari, fufu, elubo and tapioca (Balogun et al., 2012). Furthermore, cassava is considered a good source of dietary fibre which may be used to increase bulkiness and facilitate digestion. More importantly, cassava is also an important source of starch for various industrial applications.

Several factors such as processing methods, growing conditions and genotypic differences may influence the composition and physicochemical properties of cassava flour and starch. For instance, Janket et al., (2018) studied the effect of varying seasons on starch accumulation and starch granule size in cassava genotypes grown in tropic Savana climate. These authors reported that amylose content of the extracted starch was greatly influenced by genotype. Furthermore, higher temperature and solar radiation received during October and December of the growing period resulted in significantly higher starch yield and starch content compared to those planted in other periods of the year (Janket et al., 2018). Some authors similarly found significant variation in the pasting properties of two varieties of bitter yam (Oyeyinka et al., 2018). Yellow bitter yam starch reportedly displayed lower peak viscosity compared with the white bitter yam starch (Oyeyinka et al., 2018). Variation in the peak viscosities was associated with the differences in amylose contents. Other factors such as growing season and period of harvest may also influence starch granule size and amylose content, which may influence starch physicochemical properties and functionality. Asaoka et al., (1991), found variation in granule size of starch extracted from cassava root grown at different seasons. In addition, the period of harvest reportedly altered the proportion of amylose in cassava starch (Sriroth et al., 1999).

Different varieties of cassava have been bred to suit varying agro-ecological requirements and to have improved agronomic traits. However, these breeding efforts may alter composition of the roots and influence the functional properties of major components such as starch. Furthermore, 
the functionality of flour and starch from different cassava varieties grown under the same conditions may show some variations. Thus, it may be important to understand the physicochemical properties of starch and flour from cassava varieties grown at different regions. In this study, the physiochemical functional properties of flour and starch from two cassava varieties (TMS 326 and TME 419) grown at University of Ilorin Agricultural farms were investigated.

\section{MATERIALS AND METHODS}

\section{Materials}

Fresh matured cassava roots of variety TMS 326 and TME 419 were harvested from the University of llorin, Agricultural research farm. The cassava roots were immediately transferred to the food processing laboratory in the Department of Home Economics and Food Science, University of llorin for processing. All other chemicals used were laboratory-grade.

\section{Methods}

Flour production

Cassava roots $(2 \mathrm{~kg})$ were peeled manually with stainless steel knife, washed with 25 litres of potable water to remove adhering soil and then grated using a grating machine powered by Lister Diesel engine (5-1 6HP 650RPM, UK). The grated cassava was packed in bags and pressed to remove excess water, thereby reducing the cyanide content. After pressing, the cassava mash was sun dried for a total period of $24 \mathrm{hrs}$, in a batch of $8 \mathrm{hrs}$ a day. Dried samples were milled, sieved (sieve size: $(180 \mu \mathrm{m})$ and samples were packaged in Ziplock bags prior to analyses.

\section{Starch extraction}

Cassava roots $(2 \mathrm{~kg})$ were processed as described above for flour except that after grinding, the mash was submerged in 25 litres of potable water and sieving was done using a muslin cloth into a fresh bowl of potable water. The extract was left to settle for $24 \mathrm{hrs}$. After settling, the supernatant was disposed and fresh water (10 litres) was added to the sediment. The washing procedure was repeated five times until a clean white starch was obtained. Starch slurry was pressed in a muslin cloth to remove excess water and the starch sample was sun dried for a total period of $24 \mathrm{hrs}$, in a batch of $8 \mathrm{hrs}$ a day. Dried samples were milled, sieved (sieve size: (180 $\mu \mathrm{m})$ and packaged in Ziplock bags prior to analyses. 


\section{Chemical Composition of Cassava Flour}

Moisture, crude fat and total ash contents were determined using AOAC (2000) methods. Protein content was determined by the Kjeldahl method $(6.25 \times \mathrm{N})$ and total carbohydrate was calculated by difference. Crude fibre were determined by standard laboratory procedure (Olagunju et al., 2018). Mineral contents of the flour was determined as previously described using Inductively Coupled Plasma (ICP) spectroscopy (Amonsou et al., 2014).

\section{Microscopy and Objective Colour Measurement}

Starch granule morphology was examined using a scanning electron microscope (EVO $15 \mathrm{HD}$, CarL Zeiss, Jena, Germany) with an accelerating potential of $4 \mathrm{KV}$. Briefly, a thin layer of the starch granule was mounted on the aluminium specimen holder with double-sided tape. Starch samples were coated with a thin film of gold for 2 min with a thickness of about $30 \mathrm{~nm}$ (Naidoo et al., 2015).

The tristimulus $L, a, b$ parameters of starch were determined after standardization with a white tile using a Colorflex-EZ bench top spectrophotometer (A60-1014-593, Hunter Associates, Reston, VA, USA). Digital color photos were taken in duplicate and values read directly from a digital print.

\section{Amylose Contents}

The iodine binding method previously reported was used to determine the amylose content of the extracted starches (Oyeyinka et al., 2015).

\section{$X$-ray Diffraction}

X-ray diffraction patterns of cassava starches were done as described by Oyeyinka et al., (2015).

\section{Pasting Properties of Flour and Starch}

The pasting properties of cassava flour and starch were examined using a Rapid Visco-Analyzer (Newport Scientific, Australia) as previously reported (Oyeyinka et al., 2016a). Briefly, samples $(2.8 \mathrm{~g})$ were weighed into the test canister containing $25 \mathrm{ml}$ of distilled water. The mixture was agitated by mixing manually before inserting the canister into the instrument. Starch was stirred at $960 \mathrm{rpm}$ for $10 \mathrm{~s}$ before the shear input was decreased and held constant at $160 \mathrm{rpm}$ during the subsequent heating and cooling cycles.

\section{Swelling Power of Flour and Starch}

Swelling power was determined as previously reported (Oyeyinka et al., 2015). Briefly, a 1\% flour or starch suspension in water was heated for $30 \mathrm{~min}$ from 50 to $90^{\circ} \mathrm{C}$ with constant stirring. The suspension was centrifuged (model 5810R, Eppendorf International, Frankfurt, Germany) at $3400 \times \mathrm{g}$ for $20 \mathrm{~min}$ at $25^{\circ} \mathrm{C}$ and the supernatant discarded. Swelling power was obtained by 
weighing the residue after centrifugation and dividing by the original weight of flour or starch on a dry weight basis.

\section{Thermal Properties of Starch}

The gelatinisation temperatures of the starch samples were determined using a differential scanning calorimeter (SDT Q600, USA) as previously reported (Oyeyinka et al., 2016b). Briefly, starch $(3 \mathrm{mg}$ ) was weighed into the aluminum DSC pan and distilled water $(12 \mu \mathrm{l})$ added before the pan was sealed. Pans were allowed to equilibrate and samples were scanned at $10-110^{\circ} \mathrm{C}$ with an interval heating rate of $10^{\circ} \mathrm{C} / \mathrm{min}$. An empty pan was used as reference for all measurements.

\section{Statistical Analysis}

All analyses were performed in triplicate. Data were analysed using analysis of variance (ANOVA) and means were compared using the Fisher Least Significant Difference (LSD) test ( $p$ $<0.05)$.

\section{RESULTS AND DISCUSSION}

\section{Proximate and Cyanide Composition of Cassava Flour}

The proximate composition of flour from TMS 326 and TME 419 cassava roots were slightly different (Table 1). Carbohydrate (average of $84 \%$ ) was the major component in the flour samples. TME 419 flour had slightly higher carbohydrate (85.44\%) compared to TMS 326 $(83.88 \%)$. Cassava is generally known to be rich in carbohydrates including starch. UchechukwuAgua et al., (2015), similarly reported high carbohydrate content (83.63\%) for TME 419 grown in Abia state, Nigeria. Other components of the flour samples such as crude protein (average of $0.89 \%$ ), crude fat (average of $1.27 \%$ ), crude fibre (average of $2.05 \%$ ) and total ash (average of $2.25 \%)$ were generally low. Previous researchers working with five genotypes of cassava similarly reported low values for crude protein (1.2-1.8\%), crude fat $(0.1-0.8 \%)$, crude fibre (1.5$3.5 \%$ ) and total ash (1.3-2.8\%) contents (Charles et al., 2005).

Cyanide content $(7.7 \mathrm{mg} / 100 \mathrm{~g})$ of TMS 326 was higher (almost double) than that of TME 419 (Table 1). The cyanide contents of cassava root in this study were much lower than values (12-13 $\mathrm{mg} / 100 \mathrm{~g}$ ) reported by previous authors (Idowu and Akindele, 1994; Oyeyinka et al., 2019). However, some authors reported cyanide contents of $4.9 \mathrm{mg} / 100 \mathrm{~g}$ for cassava variety TME 419 grown in a different location (Uchechukwu-Agua et al., 2015). Differences in the cyanide contents may be attributed to cassava variety used and the growing conditions. Other factor such as $\mathrm{pH}$ have also been suggested to influence the cyanide content of cassava (Uchechukwu-Agua et al., 
2015). Hydrogen cyanide is a well-known anti-nutritional factor in cassava roots and is toxic for humans when consumed above certain levels. For instance, consumption above $50-100 \mathrm{mg} / \mathrm{kg}$ cyanide has been linked with acute poisoning, with reported lethality in adults (Halstrøm and Møller, 1945).

Table 1: Proximate and cyanide composition of cassava flour (\%)

\begin{tabular}{lccl}
\hline Parameters & TMS 326 & TME 419 & Mean \\
\hline Moisture & $8.84 \pm 0.12$ & $8.99 \pm 0.01$ & 8.92 \\
Protein & $1.26 \pm 0.06$ & $0.51 \pm 0.08$ & 0.89 \\
Fat & $1.59 \pm 0.13$ & $0.94 \pm 0.16$ & 1.27 \\
Fibre & $1.95 \pm 0.08$ & $2.15 \pm 0.14$ & 2.05 \\
Ash & $2.50 \pm 0.03$ & $1.99 \pm 0.09$ & 2.25 \\
Carbohydrate & $83.88 \pm 0.12$ & $85.00 \pm 0.05$ & 84.44 \\
Cyanide $(\mathrm{mg} / 100 \mathrm{~g})$ & $7.70 \pm 0.05$ & $4.30 \pm 0.01$ & 6.00 \\
\hline
\end{tabular}

\section{Mineral Composition of Cassava Flour}

The mineral composition of the cassava flours was similar with the exception of sodium and manganese (Table 2). Iron followed by magnesium, calcium and manganese were the major mineral in both cassava varieties. The values of magnesium and calcium obtained for both cassava flours are higher than the values reported previously (Charles et al., 2005). Iron is essential for the formation of haemoglobin and oxygen transport; it is also needed for increases in the resistance to infection. This result shows a low value of sodium, phosphorus, zinc and copper for both cassava flour varieties and is in agreement with the literature (Charles et al., 2005; Oboh and Akindahunsi, 2003). 
Table 2: Mineral composition of cassava flour ( $\mathrm{mg} / 100 \mathrm{~g}$ )

\begin{tabular}{lll}
\hline Parameters & TMS 326 & TME 419 \\
\hline Phosphorus & 0.057 & 0.032 \\
Zinc & 0.045 & 0.046 \\
Calcium & 0.583 & 0.584 \\
Copper & 0.137 & 0.137 \\
Manganese & 0.371 & 0.585 \\
Sodium & 0.175 & 0.175 \\
Magnesium & 0.580 & 0.585 \\
Iron & 0.853 & 0.818 \\
\hline
\end{tabular}

\section{Amylose Content of Starches}

The amylose content (approx. $27 \%$ ) of starch from TMS 326 was higher than TME 419 variety (approx. $22 \%$ ) (Figure 1). Differences in amylose content may be associated with inherent genetic differences in the plant species, botanical origin, physiological state of the plant and environmental growth conditions (Hoover et al., 2010). In this study, both cassava varieties were grown under the same conditions and were harvested at the same time. Thus, inherent genetic differences between the two cassava varieties may account for the variation in amylose content. The ratio of amylose to amylopectin in starch is well-known to influence starch functional and physicochemical properties. The amylose contents of the starches in this study are higher than values (average of 19\%) reported for starch extracted from two cassava varieties grown at two different locations in Colombia (Aldana and Quintero, 2013) but lower than value (29.29\%) reported by other authors (Nwokocha et al., 2009). 


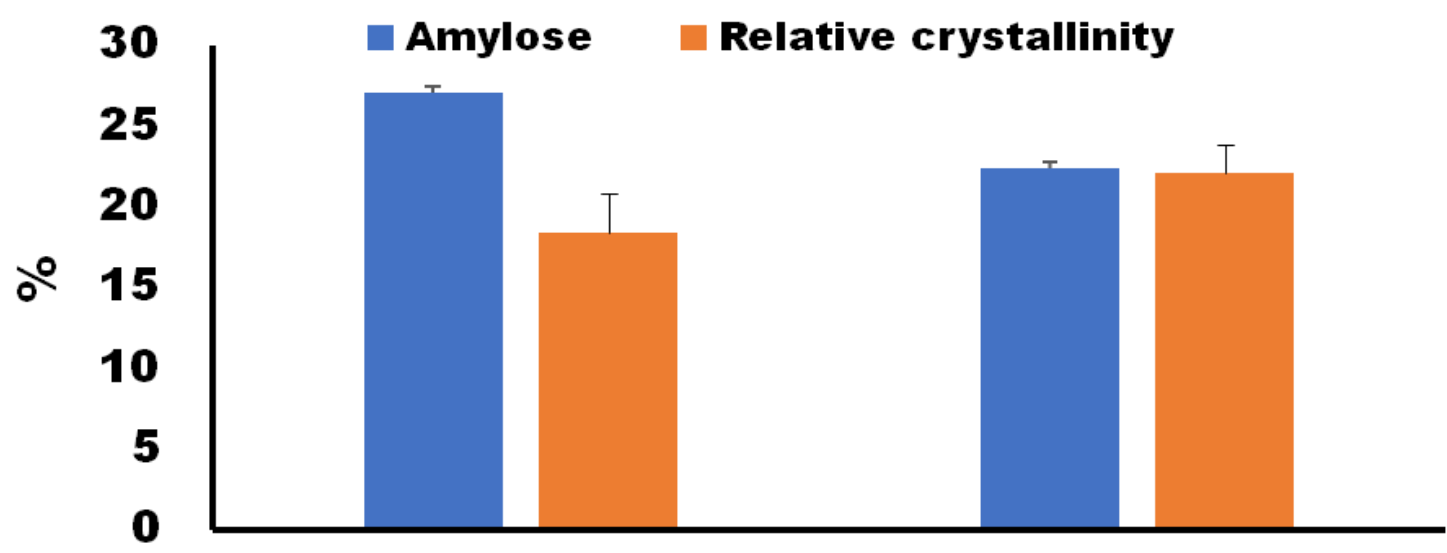

TMS 326

TME 419

\section{Cassava genotypes}

Figure 1: Amylose content of cassava starches

Error bars indicate standard deviation $(\mathrm{N}=2)$

\section{Microscopy and Colour of Cassava Starch}

By scanning electron microscope (SEM), starches extracted from TMS 326 and TME 419 had mostly round granules with some granules spherical, elongated and irregular in shape (Figure 2). Previous studies described the starch from cassava as round or spherical while some were truncated (Zhu, 2015). TMS 326 starch granules appear bigger (1.2 times) compared to those of TME 419 (Figure 2). Differences in starch granules size may be attributed to the botanical origin as well as variety of the crop. Starch extracted from TMS 326 showed diameter ranging between 6 and $20 \mu \mathrm{m}$, while those of TME 419 ranged between 7 and $21 \mu \mathrm{m}$. The average diameter (12 $\mu \mathrm{m})$ of the starch in this study is comparable to values $(11.3-15.7 \mu \mathrm{m})$ reported by Wickramasinghe et al., (2009) but slightly higher than value $(8.42 \mu \mathrm{m})$ reported for cassava starch by other authors (Nwokocha et al., 2009). All extracted starches were smooth with no fissures suggesting that these starches are relatively pure. Starch purity was assessed using the colour parameters (Table 3$)$. The $L^{*}$ value indicates whiteness ranging from white $\left(L^{*}=100\right)$ to black $\left(L^{*}=0\right), a^{*}$ value represents the value of colour in the region red $\left(+a^{*}\right)$ to green $\left(-a^{*}\right)$, while $b^{*}$ represents the colour range from yellow $\left(+b^{*}\right)$ to blue $\left(-b^{*}\right)$. Starch extracted from both cassava varieties had very high $L^{*}$ values (approx. 94), further confirming that the extracted 
starches are pure. Previous studies associated high $L^{*}$ value with high level of purity in starch samples (Oyeyinka et al., 2015).
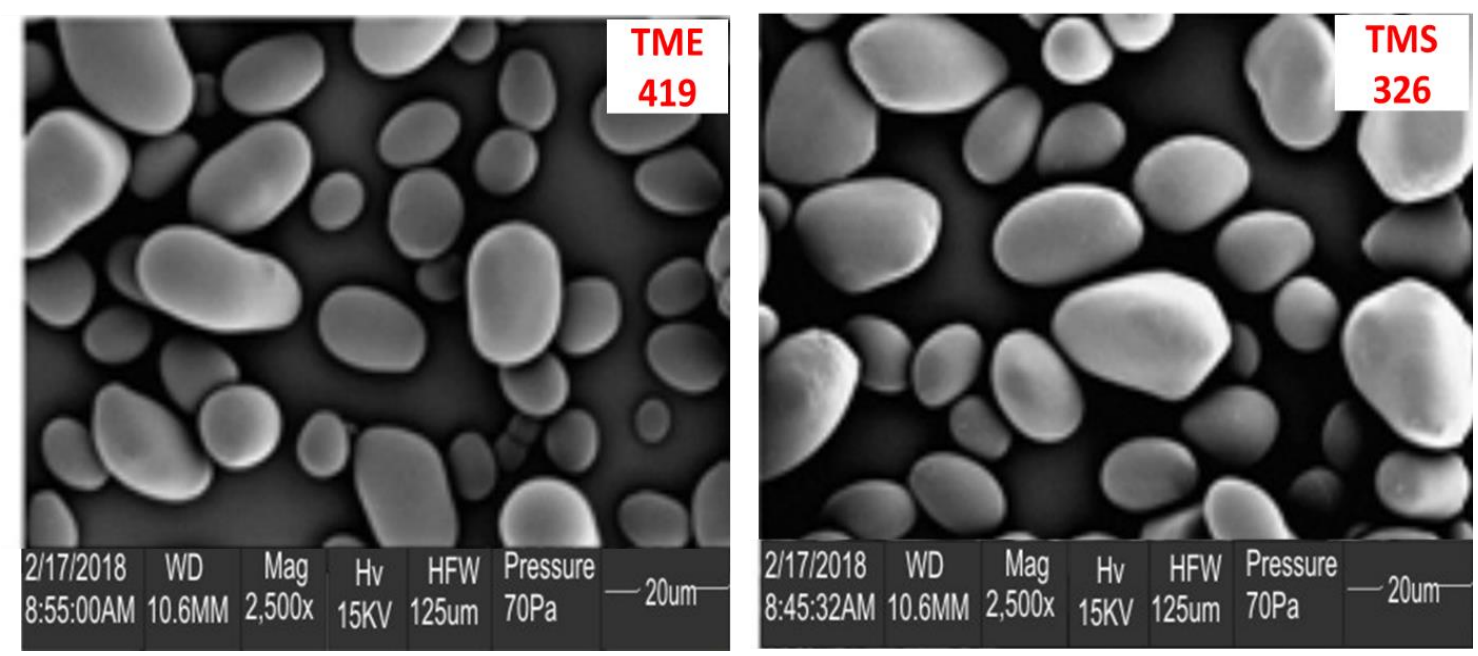

Figure 2: Microscopy of newly bred cassava starches

Table 3: Colour parameters of starch from two cassava genotypes

\begin{tabular}{lll}
\hline Parameters & TMS 326 & TME 419 \\
\hline $\mathrm{L}^{*}$ & $93.2 \pm 1.75$ & $96.3 \pm 0.31$ \\
$\mathrm{a}^{*}$ & $-0.67 \pm 0.03$ & $-1.28 \pm 0.40$ \\
$\mathrm{~b}^{*}$ & $4.66 \pm 0.05$ & $4.65 \pm 0.33$
\end{tabular}

Values expressed as Mean \pm Standard deviation.

\section{X-ray Diffraction Pattern of Cassava Starch}

The X-ray diffraction pattern of starches extracted from TME 419 and TMS 326 cassava roots is shown in Figure 3. Both starch samples exhibited strong peaks at 15 , a doublet at 17 and 18 and another peak at $23(2 \theta)$, suggesting that the samples are A-type starch. Most of the studies reported for cassava starch in the literature similarly found the A-type crystalline pattern (Anggraini et al., 2009; Charoenkul et al., 2011; Nwokocha et al., 2009). However, some authors found the Ca-type for cassava starch (Asaoka et al., 1991, 1993; Safo-Kantanka and Owusu-Nipah, 1992). Starch may show different crystallinity pattern such as type A, B and C 
depending on the botanical origin of the starch (Imberty and Perez, 1988). The differences in the crystalline types are in their packing arrangements and helical water contents. In general, A-type crystallinity is reported for cereal starches, B-type for tuber starches and C-type for legume starches. Many factors such as processing conditions may influence the crystalline patterns of starch. For example, previous research found that increasing the moisture content of starch led to a change of crystalline pattern from A-type to the C-type (Da Cruz Francisco et al., 1996).

The relative crystallinity $(R C)$ of starch from TMS 326 (18.4\%) was lower than that of TME 419 (22.1\%) (Figure 1). The lower RC of TMS 326 may be explained by its high amylose content (Figure 1). Starch RC is inversely related to the amylose content since the side chains of amylopectin forms the crystalline structure in starches (Sandhu and Lim, 2008).

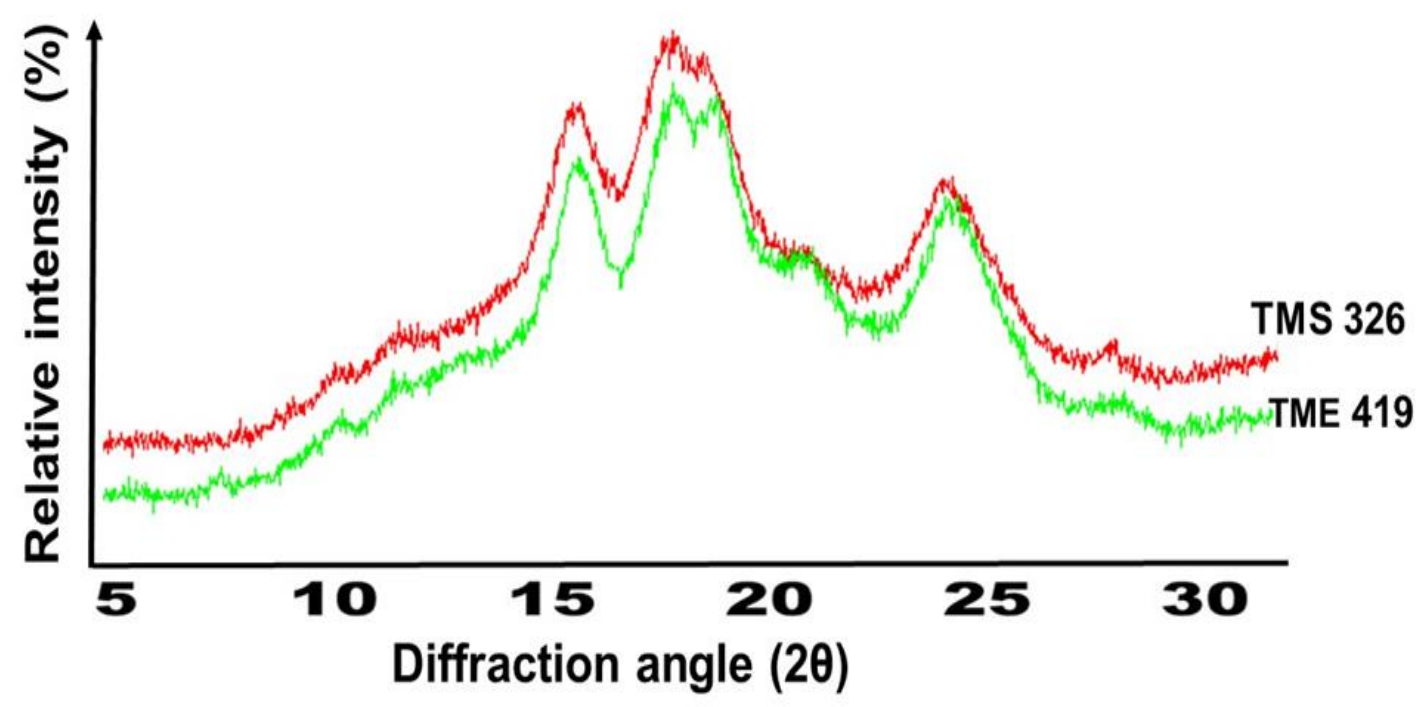

Figure 3: Diffractograms of cassava starches

\section{Pasting Properties of Cassava Flour and Starch}

The pasting properties of starches and flours were significantly $(p<0.05)$ different between the two cassava varieties (Table 4). Peak viscosity which represents the swelling peak was higher for the starch samples compared with the flour. This is expected because the presence of non-starch components such as fibre and proteins may limit the absorption of water resulting in lower peak viscosity. Cassava flour from TMS 326 had higher fat $(1.59 \%)$ and protein $(1.26 \%)$ contents (Table 1), which may account for the lower swelling power compared with the flour from TME 419 
cassava. The peak viscosity of the starch samples showed a different trend between the two cassava varieties. TMS 326 starch had higher peak viscosity (480.5 RVU) than the TME 419 sample (439.1 RVU). Several factors including starch granule size, chain length distribution of amylopectin chain and amylose content may influence the peak viscosity of starch. In general, low amylose starch displays high peak viscosity. However, in this study, TME 419 with a lower amylose $(22.1 \%)$ showed low peak viscosity, suggesting that other factors were responsible for the variation in peak viscosity. Huang et al., (2007), studied the effect of chain length distribution on the physicochemical properties of cowpea and chickpea starches. These authors reported that cowpea starch with more proportions of long chain amylopectin exhibited higher peak viscosity (Huang et al., 2007). Thus, it seems TMS 326 has higher proportions of long chain amylopectin. Cold paste viscosities of flour and starch samples were generally higher than their hot paste viscosities (Table 4). This could be due to the influence of temperature on viscosity of biological materials. Starch extracted from TME 419 had significantly higher cold paste viscosity (599.9 RVU) than starch from TMS 326 (349.9 RVU), which could be due to the difference in carbohydrate contents (Table 1).

Breakdown viscosity measures the susceptibility of the starch granule to disintegrate during heating and this may affect the stability of the flour product (Oyeyinka et al., 2019). The breakdown viscosity of the flours (approx. 211) is significantly different compared to that of starch (approx. 158) (Table 4).

The pasting temperature of TMS $326\left(80.1^{\circ} \mathrm{C}\right)$ and TME $419\left(76.3^{\circ} \mathrm{C}\right)$ starches are within the range of the values $\left(60-80^{\circ} \mathrm{C}\right)$ previously reported for tuber starches (Ezeocha and Okafor, 2016; Farhat et al., 1999). Pasting temperature represent the temperature at which the sample will cook. The variation in pasting temperature of the extracted starches could be due to differences in the granules size (Figure 2). TMS 326 starch samples were bigger than the TME 419. Bigger starch granules may require longer time to hydrate and melt compared with starch granules that are small. 
Table 4: Pasting properties of starch extracted from two cassava genotypes

\begin{tabular}{|c|c|c|c|c|}
\hline \multirow[t]{2}{*}{ Parameters } & \multicolumn{2}{|c|}{ TMS 326} & \multicolumn{2}{|c|}{ TME 419} \\
\hline & Flour & Starch & Flour & Starch \\
\hline PV (RVU) & $256.8^{d} \pm 5.32$ & $480.5^{a} \pm 9.70$ & $337.7^{c} \pm 1.68$ & $439.1^{b} \pm 16.7$ \\
\hline HPV (RVU) & $80.2^{c} \pm 0.35$ & $255.1^{b} \pm 3.92$ & $80.9 c \pm 0.79$ & $335.7^{a} \pm 4.82$ \\
\hline CPV (RVU) & $195.9 \div \pm 3.58$ & $349.9^{b} \pm 0.95$ & $162.8^{d} \pm 0.15$ & $599.9^{a} \pm 0.37$ \\
\hline $\mathrm{BDV}(\mathrm{RVU})$ & $169.3^{c} \pm 1.04$ & $221.2^{b} \pm 0.25$ & $252.9 \mathrm{a} \pm 4.39$ & $94.9 \mathrm{~d} \pm 0.04$ \\
\hline PT $\left({ }^{\circ} \mathrm{C}\right)$ & $70.7 c \pm 0.35$ & $80.1 \mathrm{a} \pm 0.04$ & $63.8^{b} \pm 0.91$ & $76.3^{b} \pm 0.70$ \\
\hline Peak time (min) & $5.88^{a} \pm 0.13$ & $4.26 \div \pm 0.03$ & $4.48^{b} \pm 0.02$ & $4.39 \mathrm{bc} \pm 0.02$ \\
\hline
\end{tabular}

Mean \pm SD. Mean with different superscript along the row are significantly different $(p<0.05)$

PV: Peak viscosity; HPV: Hot paste viscosity; CPV: Cold paste viscosity; BDV: Breakdown viscosity; PT: Pasting temperature.

\section{Thermal Properties of Cassava Starch}

TMS 326 showed a significantly $(p<0.05)$ higher onset gelatinisation $\left(T_{0}\right)$, peak gelatinisation $\left(T_{p}\right)$ and conclusion gelatinisation temperatures $\left(T_{c}\right)$ compared with TME 419 (Table 5). The differences in gelatinisation temperatures between the two cassava genotypes could be related to the higher amylose content of TMS 326 (Figure 1). Furthermore, it has been suggested that the gelatinisation temperatures of starch depends on the distribution of short chains amylopectin rather than the proportion of amylose to amylopectin (Noda et al., 1996). Starches with abundant short chain amylopectin will generally display low gelatinisation temperature compared with those with longer amylopectin chains. Earlier studies reported a higher peak viscosity for cowpea starch with more proportions of long chain amylopectin (Huang et al., 2007). Noda et al., (1996), also reported that low values of peak viscosity in sweet potato and wheat starches was due to the presence of abundant short amylopectin chains. Thus, it seems that TME 419 has higher proportion of short amylopectin chains and this possibly explains the lower peak viscosity of TME 419 starch (Table 4) and agrees with the small granule size of the starch (Figure 2). TME 419 showed a higher gelatinisation enthalpy (4.42 J/g) than that of TMS 326 (3.88 J/g) (Table 5). The gelatinisation enthalpy $(\Delta \mathrm{H})$ of the starch granules is associated with the energy required for breaking of double helices. It is a reflection of the loss of double helical order (Cooke and Gidley 1992) or the overall crystallinity of amylopectin (Tester and Morrison, 1990). 
Table 5: Thermal properties of starch from two cassava genotypes

\begin{tabular}{ccccc}
\hline Samples & $\mathrm{T}_{\mathrm{o}}\left({ }^{\circ} \mathrm{C}\right)$ & $\mathrm{T}_{\mathrm{p}}\left({ }^{\circ} \mathrm{C}\right)$ & $\mathrm{T}_{\mathrm{c}}\left({ }^{\circ} \mathrm{C}\right)$ & $\Delta \mathrm{H}(\mathrm{J} / \mathrm{g})$ \\
\hline TMS 326 & $67.60 \pm 0.71$ & $71.48 \pm 0.04$ & $76.10 \pm 0.57$ & $3.88 \pm 0.01$ \\
& & & & \\
TME 419 & $54.97 \pm 0.07$ & $61.11 \pm 0.98$ & $73.65 \pm 1.20$ & $4.42 \pm 0.07$ \\
\hline
\end{tabular}

$T_{0}$ : Onset gelatinisation temperature; $T_{p}$ : Peak gelatinisation temperature; $T_{c}$ : Conclusion gelatinisation temperature; $\Delta \mathrm{H}$ : Gelatinisation enthalpy

\section{Swelling Power of Cassava Flour and Starch}

The swelling power of cassava flours and starches generally increased with increase in temperature (Figure 4). Cassava starches showed significantly higher swelling than their flour counterparts. This is expected because starch is relatively pure while flour contains other minor constituents which limit the rate of swelling. Starch extracted from TME 419 cassava root displayed higher swelling than TMS 329, which could be attributed to the lower amylose content (Figure 1) and smaller granule size (Figure 2) of the TME 419 starch. Previous studies indicated that starches with low amylose content will exhibit higher swelling power (Oyeyinka et al., 2015). Other factors such as botanical sources, starch granule size, the magnitude of interactions between amorphous and crystalline regions may also influence the swelling power of starch (Naidoo et al., 2015) and the molecular structure of amylose and amylopectin (Oyeyinka and Oyeyinka, 2018). In comparison with potato starch, the swelling power of the cassava starches in this study seems very low. This may be attributed to the high phosphate monoester content in potato starch which has been reported to contribute significantly to greater hydration and swelling of potato starch granules (Jane et al., 1999; Mcpherson and Jane, 1999). 

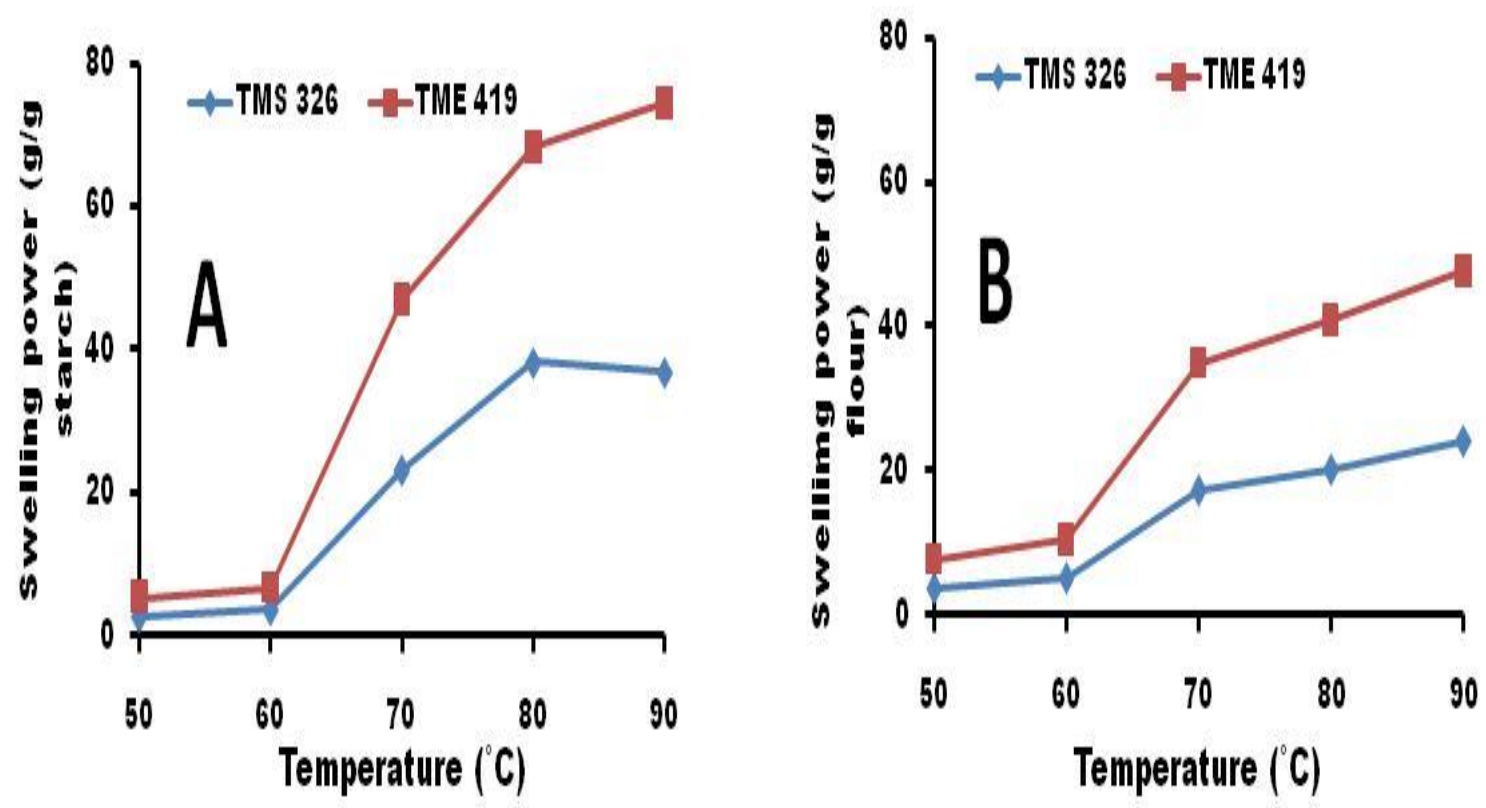

Figure 4: Swelling power of starch and flour from two cassava genotypes A: Starch; B: Flour

\section{CONCLUSION}

Cassava varieties TME 419 and TMS 326 are good sources of carbohydrate including starch. TME 419 showed significant variations in proximate composition as compared to TMS 326. TMS 326 showed significantly higher crude protein, crude fats and total ash contents than the TME 419 root. Amylose contents of TMS 326 starch were higher than TME 419 starch. Cassava starch granules of both genotypes had smooth surfaces with round shapes and some portions being irregular, elongated, and spherical in shape. Both starch types showed the A-type crystalline pattern. The peak gelatinisation temperature of TMS 326 starch was higher than that of TME 419 starch. Starch peak viscosity of TMS 326 was significantly higher than that of TME 419, which could be related to the higher amylose content. 


\section{REFRENCES}

Adisa, R. S., Adefalu, L. L., Olatinwo, L. K., Balogun, K. S., and Ogunmadeko, O. O. (2015). Determinants of post-harvest losses of yam among yam farmers in Ekiti State, Nigeria. Bulletin of the Institute of Tropical Agriculture, Kyushu University, 38, 073-078.

Aldana, A. S., and Quintero, A. F. (2013). Physicochemical Characterization of two cassava (Manihot esculenta Crantz) starches and flours. Revista Scientia Agroalimentaria, 1, 19-25.

Amonsou, E. O., Siwela, M., and Dlamini, N. (2014). Chemical composition and microstructure of Bauhinia grains. Journal of Food Science and Technology, 51 (9), 2263-2269.

Anggraini, V., Sudarmonowati, E., Hartati, N. S., Suurs, L., and Visser, R. G. (2009). Characterization of cassava starch attributes of different genotypes. Starch-Stärke, 61 (8), 472-481.

AOAC. (2000). Offcial methods of analysis. 17th edition. In: Asscoaition of official Analytical Chemists, Rockville.

Asaoka, M., Blanshard, J., and Rickard, J. (1991). Seasonal effects on the physico-chemical properties of starch from four cultivars of cassava. Starch-Stärke, 43 (12), 455-459.

Asaoka, M., Blanshard, J., and Rickard, J. (1993). The effect of pre-harvest pruning on the quality of cassava starch. Annals of Applied Biology, 122 (2), 337-344.

Balogun, M., Karim, O., Kolawole, F., and Solarin, A. (2012). Quality attributes of tapioca meal fortified with defatted soy flour. Agrosearch, 12 (1), 61-68.

Charles, A. L., Sriroth, K., and Huang, T.C. (2005). Proximate composition, mineral contents, hydrogen cyanide and phytic acid of 5 cassava genotypes. Food Chemistry, 92 (4), 615-620.

Charoenkul, N., Uttapap, D., Pathipanawat, W., and Takeda, Y. (2011). Physicochemical characteristics of starches and flours from cassava varieties having different cooked root textures. LWT-Food Science and Technology, 44 (8), 1774-1781.

Cooke, D., and Gidley, M. J. (1992). Loss of crystalline and molecular order during starch gelatinisation: origin of the enthalpic transition. Carbohydrate Research, 227, 103-112.

Da Cruz Francisco, J., Silverio, J., Eliasson, A.-C., and Larsson, K. (1996). A comparative study of gelatinization of cassava and potato starch in an aqueous lipid phase (L2) compared to water. Food Hydrocolloids, 10 (3), 317-322.

Ezeocha, C. V., and Okafor, J. C. (2016). Evaluation of the chemical, functional and pasting properties of starch from trifoliate yam (Dioscorea dumetorum) landraces. European Journal of Advanced Research in Biological and Life Sciences, 4 (2), 53-62. 
Ezui, K., Leffelaar, P., Franke, A., Mando, A., and Giller, K. (2018). Simulating drought impact and mitigation in cassava using the LINTUL model. Field Crops Research, 219, 256272.

Falola, A., Salami, M., Bello, A., and Olaoye, T. (2017). Effect of yam storage techniques usage on farm income in Kwara State, Nigeria. Agrosearch, 17(1), 54-65.

Farhat, I. A., Oguntona, T., and Neale, R. J. (1999). Characterisation of starches from West African yams. Journal of the Science of Food and Agriculture, 79 (15), 2105-2112.

Halstrøm, F., and Møller, K. O. (1945). The content of cyanide in human organs from cases of poisoning with cyanide taken by mouth. With a contribution to the toxicology of cyanides. Basic \& Clinical Pharmacology \& Toxicology, 1(1), 18-28.

Hoover, R., Hughes, T., Chung, H., and Liu, Q. (2010). Composition, molecular structure, properties, and modification of pulse starches: A review. Food Research International, 43(2), 399-413.

Huang, J., Schols, H. A., Van Soest, J. J., Jin, Z., Sulmann, E., and Voragen, A. G. (2007). Physicochemical properties and amylopectin chain profiles of cowpea, chickpea and yellow pea starches. Food Chemistry, 101(4), 1338-1345.

Idowu, M., and Akindele, S. (1994). Effect of storage of cassava roots on the chemical composition and sensory qualities of gari and fufu. Food Chemistry, 51(4), 421-424.

Imberty, A., and Perez, S. (1988). A revisit to the three-dimensional structure of B-type starch. Biopolymers: Original Research on Biomolecules, 27(8), 1205-1221.

Jane, J., Chen, Y., Lee, L., McPherson, A., Wong, K., Radosavljevic, M., and Kasemsuwan, T. (1999). Effects of amylopectin branch chain length and amylose content on the gelatinization and pasting properties of starch 1. Cereal Chemistry, 76(5), 629-637.

Janket, A., Vorasoot, N., Toomsan, B., Kaewpradit, W., Banterng, P., Kesmala, T., and Jogloy, S. (2018). Seasonal Variation in Starch Accumulation and Starch Granule Size in Cassava Genotypes in a Tropical Savanna Climate. Agronomy, 8(12), 297.

Maziya-Dixon, B., Alamu, E. O., Popoola, I. O., and Yomeni, M. (2017). Nutritional and sensory properties: Snack food made from high-quality cassava flour and legume blend. Food Science and Nutrition, 5(3), 805-811.

McPherson, A., and Jane, J. (1999). Physicochemical properties of selected root and tuber starches. Carbohydrate Polymers, 40, 57-70.

Naidoo, K., Amonsou, E., and Oyeyinka, S. (2015). In vitro digestibility and some physicochemical properties of starch from wild and cultivated amadumbe corms. Carbohydrate Polymers, 125, 9-15. 
Noda, T., Takahata, Y., Sato, T., Ikoma, H., and Mochida, H. (1996). Physicochemical properties of starches from purple and orange fleshed sweet potato roots at two levels of fertilizer. Starch-Stärke, 48(11-12), 395-399.

Nwokocha, L. M., Aviara, N. A., Senan, C., and Williams, P. A. (2009). A comparative study of some properties of cassava (Manihot esculenta, Crantz) and cocoyam (Colocasia esculenta, Linn) starches. Carbohydrate Polymers, 76(3), 362-367.

Oboh, G., and Akindahunsi, A. (2003). Biochemical changes in cassava products (flour \& gari) subjected to Saccharomyces cerevisae solid media fermentation. Food Chemistry, 82(4), 599-602.

Oladipo, F., Bolarin, O., Daudu, A., Kayode, A., and Awoyele, P. (2017). Utilization of soil conservation practices among root and tuber farmers in Oyun Local Government Area of Kwara State, Nigeria. Agrosearch, 17(2), 99-109.

Olagunju, O. F., Ezekiel, O. O., Ogunshe, A. O., Oyeyinka, S. A., and ljabadeniyi, O. A. (2018). Effects of fermentation on proximate composition, mineral profile and antinutrients of tamarind (Tamarindus indica L.) seed in the production of daddawa-type condiment. LWT-Food Science and Technology, 90, 455-459.

Oyeyinka, S. A., Adeleke, O. F., Dauda, A. O., Abiodun, O. A., Kayode, R. M., and Adejuyitan, J. A. (2018). Flour composition and physicochemical properties of white and yellow bitter yam (Dioscorea dumetorum) starches. Industrial Crops and Products, 120, 135-139.

Oyeyinka, S. A., Ajayi, O. I., Gbadebo, C. T., Kayode, R. M., Karim, O. R., and Adeloye, A. A. (2019). Physicochemical properties of gari prepared from frozen cassava roots. LWTFood Science and Technology, 99, 594-599.

Oyeyinka, S. A., and Oyeyinka, A. T. (2018). A review on isolation, composition, physicochemical properties and modification of Bambara groundnut starch. Food Hydrocolloids, 75, 6271.

Oyeyinka, S. A., Singh, S., Adebola, P. O., Gerrano, A. S., and Amonsou, E. O. (2015). Physicochemical properties of starches with variable amylose contents extracted from bambara groundnut genotypes. Carbohydrate Polymers, 133, 171-178.

Oyeyinka, S. A., Singh, S., and Amonsou, E. O. (2016a). Physicochemical properties of starches extracted from bambara groundnut landraces. Starch-Stärke, 69(3-4), 1-8.

Oyeyinka, S. A., Singh, S., Ying, M., and Amonsou, E. O. (2016b). Influence of high-pressure homogenization on the physicochemical properties of bambara starch complexed with lysophosphatidylcholine. LWT-Food Science and Technology, 74, 120-127. 
Safo-Kantanka, O., and Owusu-Nipah, J. (1992). Cassava varietal screening for cooking quality: relationship between dry matter, starch content, mealiness and certain microscopic observations of the raw and cooked tuber. Journal of the Science of Food and Agriculture, 60(1), 99-104.

Sandhu, K. S., and Lim, S. T. (2008). Digestibility of legume starches as influenced by their physical and structural properties Carbohydrate Polymers, 71(2), 245-252.

Sriroth, K., Santisopasri, V., Petchalanuwat, C., Kurotjanawong, K., Piyachomkwan, K., and Oates, C. (1999). Cassava starch granule structure-function properties: influence of time and conditions at harvest on four cultivars of cassava starch. Carbohydrate Polymers, 38(2), 161-170.

Tester, R. F., and Morrison, W. R. (1990). Swelling and gelatinization of cereal starches. I. Effects of amylopectin, amylose, and lipids. Cereal Chemistry, 67(6), 551-557.

Uchechukwu-Agua, A. D., Caleb, O. J., Manley, M., and Opara, U. L. (2015). Effects of storage conditions and duration on physicochemical and microbial quality of the flour of two cassava cultivars (TME 419 and UMUCASS 36). CyTA-Journal of Food, 13(4), 635645.

Wickramasinghe, H. A. M., Takigawa, S., Matsuura-Endo, C., Yamauchi, H., and Noda, T. (2009). Comparative analysis of starch properties of different root and tuber crops of Sri Lanka. Food Chemistry, 112(1), 98-103.

Zhu, F. (2015). Composition, structure, physicochemical properties, and modifications of cassava starch. Carbohydrate Polymers, 122, 456-480. 